\title{
Refugees: Post Traumatic Stress, and Crime - Experiences from Germany
}

\begin{abstract}
The immigration of refugees since 2014, especially from North African Countries has the last year an increasing critical political discussion in the population, also in Germany, the goal of many migrants. While on the background of political signals at the beginning of the movement refugees were welcome by the majority of the population, meanwhile criticism is more and more expressed in the media and political discussion. In many European Countries right wing parties were established, also in Germany (Alternative für Deutschland - AfD). The last vote for the European Parliament shows for Germany an increasing acceptance of this party, especially in Eastern Germany, the former German Democratic Republic. Very often the public is not very well informed by the media. On one side there are reports of an increasing crime rate, without differenciating the background of, on the other side the German industry needs the immigrants, there are many open positions for workers. The chapter gives a short overview about the discussion about the topic in Germany.
\end{abstract}

\section{Keywords:}

refugees and migrants, situation in Germany, right wing partys, immigration politics, refugees and crime rate

1 University of Freiburg, Freiburg, Germany. E-MAIL: helmut.kury@web.de 
"We lost our home, which means the familiarity of daily life.

We lost our occupation, which means the confidence that we are of some use in this world. We lost our language, which means the naturalness of reactions, the simplicity of gestures, the unaffected expression of feelings.

We left our relatives... and our best friends have been killed... and that means the rupture of our private lives."

Hannah Arendt (1943, p. 71)

\section{INTRODUCTION}

In recent years - though especially since 2014 - Western European countries (and Germany in particular), have experienced a high number of refugee claims, mostly from citizens of Syria, Iraq, Iran, and Afghanistan. Despite a broad "Willkommenskultur" (welcoming culture), more and more politicians, especially those from a new political party "Alternative für Deutschland - AfD" (Alternative for Germany), have warned that Germany might be overburdened by too many foreigners in the country. Similar political discussions have occurred in other European countries, too (Möllers \& Ooyen, 2018; Toshkov \& Kortenska, 2015). The situation caused many right wing politicians to warn against an excessive burden due to the foreign infiltration. On the other side, experts from economy pointed out that German industry has a lot of open positions and on the background of a low birth rate in the country needs more and more foreign workers. On one side, immigrants are expensive for the country - if they do not have a job, the country has to pay for their living costs and in cases of (psychological) diseases, for treatment and rehabilitation; if they commit crimes, may be for incarceration; on the other side - if they are integrated and work, they pay taxes and help to bring the country forward. The goal of the chapter is to present information about the psychological situation of refugees and their deviant behaviour to engage a more valid and reality based discussion. Media reports about the topic of refugees very often are not based on facts (Hestermann, 2018).

This chapter presents first a short overview about the controversial discussion in Germany on the topic of immigration, showing different motivations about the topic. In the following, first, the results of a broad survey with refugees about the topic of Post-Traumatic Stress of the immigrants on the background of their experiences in the home countries and on the way to Europe are presented. Second, information about the crime rate of this group is shown. A final discussion will finish the chapter. 


\section{MORE REFUGEES IN GERMANY: THE PUBLIC DISCUSSION IN THE COUNTRY}

2015 is remembered in Germany as a year in which a particularly high number of refugees arrived. The Bundesamt für Migration und Flüchtlinge (2016, p. 2) registered 476,649 asylum claims, which was an increase of $135 \%$ over the number of claims in 2014 (202,834). Given that not all those who arrived in Germany claimed asylum, the real number of refugees in 2015 was considerably higher: altogether over 1 million people arrived. At the same time, the number of people leaving the country also increased. The Bundesamt für Migration und Flüchtlinge (2016, p. 2) calculated for 2015 a corrected number of immigrants of 1,139,000 persons. Most refugees come from Syria. According to the citizenship data of the Statistisches Bundesamt - Destatis (2018b), at the end of 2016 at least 10 million people with only foreign citizenship were officially registered in the German Ausländerzentralregister (AZR). This is the highest number in Germany since establishment of the AZR in 1967. The real number is likely higher as not all immigrants are officially registered. It must, however, be remembered that although the numbers have increased, refugees and migrants are not a new phenomenon: since the beginning of humankind, people have been on the move, sometimes voluntarily and sometimes involuntarily (Claussen, 2018).

Despite the increasing number of refugees and migrants, Germany has only begun to develop a systematic and effective integration policy over the last few years, a topic very often criticized. As an industrial powerhouse, many economists have pointed out the enormous need for additional manpower in Germany, particularly due to the country's declining birth rate (in 2017 only 1.57, less than the year before; Statistisches Bundesamt - Destatis, 2018b). Currently, there are not enough German citizens to fill the available jobs. Strack et al. (2015, p. 3) point out that the declining birth rate in Germany will have "enormous effects on the German labour market”. The authors predict that in 2030, between 5.8 and 7.7 million workers will be missing - "a shortage which will cost the country round about 410 to 550 billion euro because of missing industrial output” (2015, p. 3). To avoid this, they suggest it is necessary to more than "double the net number of immigrants per year" from the expected 200,000 in 2030 to 500,000 (2015, p. 11; Lien, 2016).

Brückner, Hauptmann, \& Vallizadeh (2015, p. 1) correctly point out that refugees are often not well qualified, but note that due to their low median age, they can benefit tremendously from education and professional training. Thränhardt (2015, p. 4) notes the importance of employment in the integration process: "Having a job has been pointed out again and again as an important factor for integration, especially as a key for social contacts, for positive reinforcement in the guest 
society and also for the self-esteem of immigrants” (see also Enste et al., 2016) . The author suggests (Thränhardt 2015, p. 37) that society should concentrate its integration efforts on establishing a framework in which refugees become active and are enabled to plan their own future instead of planning how to build barriers and enforce more restrictive laws (Bosen \& Wiederwald, 2018).

The UNHCR notes in its 2018 annual report that the number of refugees and forcibly displaced persons worldwide reached 68.5 million in that year. More than half of all refugees are children. The number of people who had to leave their home country increased by 16.2 million in 2017. That means that the majority of refugees stay within their own country (about 40 million). In 2017, Turkey had the largest number of foreign-born refugees living in the country, Germany the second largest.

In the meantime - and against a background of public pressure and political decisions - the number of immigrants arriving in Germany has sharply decreased. According to information provided by Mediendienst Integration (2018), from January to October 2018, 158,512 applications for asylum were presented, 17\% less than one year before. $43.2 \%$ of the asylum seekers were girls and women. Since 2016, the number of female refugees in Germany has increased by around 7\%. In 2017, Germany received a total number of 222,683 asylum applications. In mid-2018, the number of refugees living in the country was 1.1 million people. A further 400,000 claimants were waiting on a decision about asylum or contesting their right to remain in the country. Around 99,000 asylum seekers who have their claims denied are "tolerated" (“Geduldete”) in Germany (Diekmann, 2016).

As the figures above show, Germany has increasingly become a desirable destination for refugees and immigrants (Bundesamt für Migration und Flüchtlinge, 2016, p. 10). From the 84.4 million inhabitants in Germany in 2015, 17.1 million had a migration background, that is, the person themselves or at least one of their parents did not have German citizenship by birth (Bundesamt für Migration und Flüchtlinge, 2016, p. 11; see also Haverkamp, 2016, 2018).

The tremendous increase of immigrants in Germany has led to fear and resentment amongst segments of the population, and concerns have been raised, at times via sensationalist media reporting, that Germany will not be able to manage (Hestermann, 2018; Ilić, 2018). However, a representative German survey conducted in July and August 2018, asking persons aged 14 and older, found that no less than $80 \%$ define helping immigrants as a characteristic of a good citizen (Kösemen, 2018, p. 13). People with a migrant background point out in the survey, in comparison to natives, that it is especially important to respect different religions (+ 10\%), to help immigrants (+ 9\%) and to accept law and order and to take care of the environment (both $+6 \%$ ) $(2018$, p. 15). Altogether, the ratings about 
what characterizes a good citizen are very similar among the respondents with and without a migrant background (2018, p. 21). The results show that German citizens and migrants are not divided in their attitudes about basic topics of living together and generally agree on the most important characteristics of being a good person in Germany (2018, p. 27).

Although the "Willkommenskultur" is still in existence throughout large parts of Germany and numerous efforts are being undertaken to engage and interact with the newcomers, legal and political efforts are increasingly seeking to reduce the number of immigrants and increase the number of individuals returned to their country of origin. One reason for these political and legal developments is a reaction to a number of severe crimes committed by young male immigrants (Balica et al., 2018; Walburg, 2018; Willems \& van Santen, 2018). The commission of crime by immigrants has also resulted in an increase in the number of foreign prisoners and has created language difficulties for prison authorities (Aebi et al., 2018; Schaffer \& Obergfell-Fuchs, 2018). Crime committed by immigrants has led to discussions about how refugees increase the crime rate in Germany and how, in the context of their cultural traditions and current living conditions, their criminal behaviour can be understood (Feltes, List, \& Bertamini, 2018; Heinz, 2012; Ammar, 2014; Light \& Miller, 2018; Balica et al., 2018; Enzmann \& Kammigan, 2018).

Data from the Bundeskriminalamt (2018) shows that the number of registered criminal acts committed by immigrants has increased. However, very often the victims of these criminal acts are also immigrants (Ramm, 2018). The criminal activities must therefore be understood in the context of the poor living conditions of these people, but also on different religions and educational backgrounds, for example, on the position of women in society. The data also show that the number of crimes carried out by Germans against asylum homes and their occupants has decreased.

An annual survey of a representative sample of adult German citizens shows an increasing number of people feeling unsafe and fearful outside their homes (Infocenter der R+V Versicherung, 2018). The results from 2018 show that 63\% of the sample worry about increasing problems due to the growing numbers of asylum seekers; $63 \%$ also fear societal tensions between locals and foreigners (although the number is slightly lower than in the 2016 survey).

These fears and insecurities have led to increasing societal polarization. The "Willkommenskultur" has increasingly been called into question and an evergrowing segment of the population is demanding that changes be made to the country's asylum policies. Already in autumn 2014, 61\% of the German population was against increased immigration from outside the European Union (Eurobarometer, 2014, p. 6; Haverkamp, 2016, p. 2). The topic of refugees has also been taken-up by 
right-wing parties in Europe, including the AfD in Germany: these parties have (more or less aggressively) called for a complete stop to immigration.

Although a very large number of volunteers have sought to help the immigrants, to teach them German and to provide assistance to show them how to fill out official forms and deal with governmental institutions (Jiranek, Wehner, \& Kals, 2015), some sections of the public still refuse to acknowledge, shame or attack immigrants and their dwellings. The living conditions in overloaded mass camps, particularly at the beginning of the immigration wave, were often frustrating, especially as it was often unclear whether the persons would be allowed to stay in Germany or have to leave again. Such uncertainty can result in criminal behaviour, especially among young men. Constructive model projects can, however, be conducted to better integrate (particularly juvenile) migrant offenders. A good example of one such model project is "Integration by the Integrated" (conducted in Schleswig-Holstein in the north of Germany; Ministerium für Inneres, ländliche Räume und Integration Schleswig-Holstein, 2018). It is, however, important to realise that engagement by volunteers is not of its own sufficient to support the majority of refugees.

The development of the situation of refugees in Germany must be viewed against the background of different attitudes in the population and the official governmental institutions. On the one hand, the politics of immigration in Germany is increasingly criticized by both sides of the political spectrum and alternatives are being sought to reduce the "refugee problem" (e.g., by increasing investments in the home countries of the refugees). On the other hand, media reports about the situation and the fate of the immigrants in their home countries, especially in Syria, and on conditions suffered during the flight to Europe, are shocking. Statista (2018) estimates that the number of refugees who drowned in the Mediterranean was 3,283 in 2014, 5,143 in 2016, and 2,133 in 2018. Media reports about increasing crime rates and severe crimes conducted by immigrants have, however, also increased the number of people who refuse to accept more immigrants. In the following chapter we will present data from a broad survey asking refugees about posttraumatic stress on the background of their experiences.

\section{RESULTS FROM A GERMAN SURVEY ON POST-TRAUMATIC STRESS DISORDER (PTSD) AMONG REFUGEES}

Several publications point out the physical and psychological burdens experienced by refugees due to the situation in their home countries and, additionally, their 
experiences on the way to Europe/Germany (Hillebrecht, Zeiss, \& Bengel, 2018; Knipper \& Bilgin, 2009). The European Commission (2004; see also Council of Europe, 2005; Ludwig, 2016) points out that stressful experiences during their flight are often not given enough attention (Bundes Psychotherapeuten Kammer, 2015). As Gäbel et al. (2005; see also Ruf, Schauer, \& Elbert, 2010) emphasize, due to the dramatic experiences on the way to Europe, symptoms of a Post-Traumatic Stress Disorder - PTSD - are often found amongst refugees. Often there are existing anxieties and depression; suicidal behaviour is also not uncommon (Dilling, Mombour, \& Schmidt, 2013; Täubig, 2009; Teegen, 2003). Children often show slow development and deviant behaviour, which can result also in criminal activities (Flatten et al., 2011; Bundes Psychotherapeuten Kammer, 2015, p. 6). A report by the German government (Deutscher Bundestag, 2018, p. 5ff) discusses the particularly perilous situation of unaccompanied minors. On February 1, 2017, there were officially 43,840 unaccompanied minors living in Germany (under 14 years), though the unofficial number is likely much higher on the background of a high dark number. To help this group and to integrate them in society, especially if they have psychological traumas, is very important but can be also very expensive.

In their research project about "Relations between trauma exposure, post-resettlement stressors, perceived discrimination, and mental health symptoms in Somali adolescent refugees resettled in the U.S.”, Ellis et al. (2008, p. 184) found, by exploring a group of subjects between 11 and 20 years old, that the "results indicated that cumulative trauma was related to PTSD and depression symptoms. Further, postresettlement stressors, acculturative stressors, and perceived discrimination were also associated with greater PTSD symptoms after accounting for trauma, demographic, and immigration variables. Number of years since resettlement in the US and perceived discrimination were significantly related to depressive symptoms, after accounting for trauma, demographic, and immigration variables”.

Concerning refugees, Gojer \& Ellis (2014, p. 5) discuss “extraordinary rates of mental illness including PTSD (84\%), depression (61\%), dementia/traumatic brain injury (0.5\%) and cognitive limitations (9\%)” (see also Moran, 2013). Rousseau et al. (2011) point out that 44\% of refugees with PTSD also had additional problems, such as depression. Fazel, Wheeler, \& Danesh (2005) also found increased rates of depression and anxiety amongst refugees (Lindert et al., 2008, p. 110). As a means of comparison, the prevalence of depression in the general public is estimated to be 3-7\%, concerning PTSD 1-14\% (Kessler, 2007). Treatment of refugees in cases of psychological problems very often is hindered by language problems. Refugees often do not speak German when they arrive and psychotherapists who speak their language are very rare. 
In our empirical survey (see Kury, Dussich, \& Wertz, 2018; Kury \& Redo, 2018) we anonymously asked refugees in camps in the region of Munich, Freilassing, Berlin, and Freiburg and surroundings. The refugees in the camps were informed about the survey in Arabic language and asked to participate. The rate of participation was very high in the group of male refugees but much lower in female refugees. The background is that more females could not read and write and in many cases the male participants did not allow them to fill out the questionnaire. So $74.1 \%$ of our sample are males and $24.8 \%$ females. Altogether, 825 refugees were asked. Most came from Syria (84.0\%), 13.5\% from Iraq. We used a standardised internationally well known questionnaire to diagnose PTSD: the PCL Checklist, Civilian Version (PCL-C) with 17 items (Australian Centre for Posttraumatic Mental Health, 2007, p. 19ff; Simon, 1995; Wilson \& Keane, 1997; Weathers et al., 1993). The 17 items are answered on a scale from 1 ("absolutely not") to 5 ("very strong"). So the summarized values range from 17 to 85 , a value of 50+ and signals a form of PTSD that needs special treatment (Australian Centre for Posttraumatic Mental Health, 2007, p. 21). The questionnaire was filled out anonymously.

The questionnaire included an introductory text about anonymity, followed by 10 questions about: - nationality of the refugee, - profession, - sex, - age, - number of years of school education, - how the person came to Germany (alone or with others), - if not alone, with whom, - preferred country of residence, - does the immigrant feel welcome in Germany, - will he/she later return to their home country if the situation there improves. A second page included the 17 questions of the PCL-C. All questions were translated into Arabic.

The results show a median total score of PCL in the whole sample of 43.9; this is relatively high. $34.8 \%$ of the sample had a value of 50 or higher, meaning a PTSD which needs professional psychological/psychiatric treatment. Interestingly, clear differences can be seen between groups of refugees living under different conditions. The highest median PTSD value of 74.2 was from a surveyed group tested close to the Austrian boarder: these individuals had just arrived in Germany and were awaiting the next steps in large centres. Very high PTSD values (median of 69.7) were also recorded amongst a group of refugees living in Berlin: these individuals lived in a large overcrowded centre, the big halls of a former airport, with very little privacy. Lower PTSD values were recorded amongst individuals in smaller accommodation centres, especially among those who lived several weeks or longer in Germany and were supported by volunteers who gave them a greater feeling of acceptance and help. 
The majority of tested refugees, 84\%, came from Syria/Palestine, another group of $13.5 \%$ from Iraq. The latter group had a medium value in the PTSD scale of 49.2, and showed a clearly higher stress than the Syrian sample (43.0). $74 \%$ of the group were male (PCL-C =43.5), 25\% female (44.8) (more men answered as a larger percentage of women could not read or write or were hindered by male partners). $36.4 \%$ informed that they have learned a trade (male $=44.2 \%$, female $=13.2 \%$ ), $31.5 \%$ had no professional education (male $=23.4 \%$, female $=56.1 \%$ ), $21.1 \%$ are students (male $=21.8 \%$, female $=19.5 \%$ ), and $8.8 \%$ academics $($ male $=5.3 \%$, female $=9.8 \%$ ). The age was from 9 to 93 years, the median age was 30 years. $1.9 \%$ were under 14 (children according the German law), 22.4\% from 14 to 21 years, 39.3\% from 22 to 30 years, $19.4 \%$ from 31 to 40 years and $16.4 \% 41$ years and older.

Children under 14 had the highest median PTSD value from all age groups (52.5). $80 \%$ of the full sample did not come alone to Germany, $16.2 \%$ came without people they knew, $56.1 \%$ came with a family member, $21.6 \%$ with friends. $72.1 \%$ feel welcome in Germany, 14.5\% mostly welcome and 5.5\% unwelcome. Refugees who feel unwelcome have a significantly higher median PTSD value (49.4) than the group feeling welcome (43.0). 37.3\% plan to return home if the situation were to improve, $13.5 \%$ are unsure and $44.0 \%$ plan to live permanently in Germany. Prior research has found that a large number of immigrants who have come to Germany in the past (for example, the so-called “Gastarbeiter") eventually returned to their country of origin (Kury, Dussich, \& Wertz, 2018, p. 341f; Bertelsmann Stiftung 2016, 2017, 2018).

\section{REFUGEES AND CRIMINAL BEHAVIOUR}

Given the high proportion of young male refugees, the high PTSD values, the (often) poor living conditions after arrival in Germany, the unclear future perspectives and possible feelings of rejection and stigmatization, it has been hypothesised by criminologists on the basic of theories about criminal behaviour that the crime rate amongst refugees must be rather high. The Bundeskriminalamt (2018a; 2018b) (Federal Police Department) provided statistics from the first quarter of 2018 that recorded 66,200 cases of attempted or completed crimes that involved at least one immigrant. In the fourth quarter of 2017, the number was 62,000 cases. The Bundeskriminalamt did point out also that the vast majority of immigrants did not commit any crimes. The registered criminal cases with involvement of immigrants can be broken down as follows: $28 \%$ financial or forgery crimes (more than half of this group is accounted for using public transport without a valid 
ticket), 23\% theft (almost two-thirds for shoplifting), 22\% assault (76\% for bodily harm), $10 \%$ drug-related crimes, $1.6 \%$ sexual assault, $0.13 \%$ homicide, $13 \%$ other miscellaneous crimes.

The crime rate in the group of Syrian, Afghani and Iraqi refugees/immigrants was relatively low, in the group of refugees from the Maghreb (Algeria, Morocco, Tunisia), Gambia, Nigeria, Somalia, and Georgia - relatively high. $79 \%$ of the assault cases involved both immigrant offenders and victims. In the first quarter of 2018, 89 cases of (attempted) homicide were registered that included at least one immigrant: in most cases both the victim and the offender were immigrant (Klingst \& Venohr, 2017). Of the 11 persons killed, 10 were immigrants. In $23 \%$ of the cases, the crime occurred in a refugee camp. On the topic of refugee camps: these have been attacked in the past by right-wing groups, though this trend has reduced from 472 attacks in the first quarter of 2015 to 42 attacks in the first quarter of 2018 (see the discussion about defining refugees and migrants by Scherr, 2018).

Over time, the number of crimes committed by immigrants has decreased. In 2017, the crime rate included 167,268 suspected immigrants: in 2016, this was 174,438 cases. The vast majority of suspected immigrants were male (87\%) and $66 \%$ were younger than 30 years old. More than half of the adults who committed a crime were between 21 and 30 years old. While the segment of immigrants asking for asylum in the age group 18 to 29 years was 37\%, the part of suspected immigrants in the same age group was $53 \%$. The segment of female immigrant suspects was 13\% (Bundeskriminalamt, 2018b, p. 14). Round about one-third of suspected immigrants were suspected to be multiple offenders (2018b, p. 16), with the majority of these coming from the Maghreb countries. While theft in 2017 declined in comparison to one year before, drug crimes increased (2018b, p. 19). In 2017, 5,258 sexual assaults occurred, in 2016 the number was smaller at 3,404.

However, the primary reason for this increase has to do with an expansion of the law concerning sexual assaults (Bundeskriminalamt, 2018b, p. 24): based on the old regulations, the number of sexual assaults in 2017 would have been 3,597 (a small increase compared to 2016). Comparing the results from the two years, the Bundeskriminalamt concluded that in terms of crimes committed by immigrants, there are clear differences between certain crimes. Concerning theft, there has been a clear reduction; concerning drug crimes, homicide and sexual assault - a clear increase (though as mentioned, this is partly due to legal changes; 2018b, p. 59). It suggests that the crime rate amongst immigrants depends on many general conditions, including positive integration, and will likely change over time. The Bundeskriminalamt also mentions the importance of monitoring organized and politically motivated crimes (2018b, p. 60). 
On the background of the increasing number of immigrants and their crime rate, the number of prisoners also increased strong, as discussed before. Since mid2000, the number of prisoners decreased in Germany but increased again the last years on the background of a higher rate of immigrants committing severe crimes. On March 31, 2018, there were round about one third of prisoners foreigners (Statistisches Bundesamt, 2018a; Schaffer \& Obergfell-Fuchs, 2018). In Hamburg the beginning of 2019, 59\% of prisoners are foreigners, especially coming from Eastern Europe, Serbia, Romania Albania, also from Morocco and Algeria. One of the biggest problems besides overcrowding are language barriers and different religions with in some part intolerant attitudes, creating conflicts (Schatz, 2019).

\section{DISCUSSION}

As highlighted above, numerous studies have shown the substantial psychological burdens immigrants face due to their experiences in their home countries and, especially, during their flight, but also in part due to conditions in their guest countries. These burdens have to be taken into account when considering psychological burdens and crimes carried out by immigrants, especially in the case of young men. Investigations have also shown the negative effects of migration and traumatic events, particularly on (younger) children (Lennertz, 2011; Bräutigam, 2000, p. 49; Erentaité et al., 2018).

Indeed, it has been found that such negative effects can lead to aggressive and violent behaviour (UNHCR, 2013). Another possible reason for criminal behaviour is the loss of status and authority felt by those who have left their country and culture behind: this is most often an experience shared by young immigrant men (Balluseck \& Ringel, 2003, p. 112f). In this context, some authors have assessed gender-specific processing strategies, especially among children and juveniles (Johansson, 2016, p. 81). Gäbel et al. (2005) report a clear increase in the suicide rate of persons with a PTSD. The Bundes Psychotherapeuten Kammer (2015) also found that $40 \%$ of refugees with a PTSD are suicidal.

Moreover, Elbert et al. (2016, p. 28) point out that in addition to a higher probability of developing a physical disease, the suicide risk clearly increases in cases of untreated PTSD. Gojer \& Ellis (2014, p. 12) point out “the barriers” immigrants and refugees face in identifying/disclosing mental health symptoms. The authors contend that in many cultures, there is a strong stigma attached to mental health problems and their treatment. This results in families and individuals failing to seek help for their psychological problems for fear that they will shame their family or be 
perceived as weak (see Kury, Dussich, \& Wertz, 2018, p. 337ff). In this context it has to be seen that in our survey especially young immigrants, children, had the highest values in PTSD beside refugees/migrants not feeling accepted in the host country. In these cases, a valid psychological treatment and professional help is necessary to avoid further problems with this group. This treatment very often is difficult to handle on the background of different languages. This is also a huge problem in dealing with criminal migrants in prisons. Many conflicts develop on the basis of different religions, in part not tolerant. Immigrants who want to live here have to be informed about the cultural values and the legal regulations in this country and have to accept it to avoid ongoing conflicts and to live in freedom here.

These factors aside, fears in Germany and Europe have continued to increase about the link between migration and crime, in particular with regard to terrorist attacks. As the Institute for Economics and Peace (2017a, p. 98; 2017b) points out: "The percentage of European citizens linking refugees with terrorism and crime was high in 2016, particularly in eastern and southern European countries”. However, partially higher crime rates among immigrants have to be understood in light of the frequently terrible experiences they have suffered in their home countries, during their migration and in their host countries.

Increasing fears in Germany very often are addressed to the "refugee problem", engaged by one sided media reports following own political interests, a problem well known and since many years discussed (Scheerer, 1978; Hestermann, 2018). The last decades, feelings of insecurity, general fears and discontent with the situation in a more and more open and complex society are increasing. In western societies people lose trust in society and democracy, especially in Europe, less in USA (Foa \& Mounk, 2017, p. 6). Wike \& Fetterolf (2018, p. 147) emphasize: "In surveys, many people say that their vote does not give them an adequate voice in national politics, that elected officials do not care what people like them think, and that average citizens could do a better job than elected officials of dealing with their country's problems”. Feltes (2019, p. 3) suggests that the general fears very often are focused by politicians and media on crime and more and more on foreigners and migrants. These fears are a problem also for support of democracy. A politics of more and more severe penal laws and sharper punishments for offenders does not focus on the real background of the anxieties in societies and does not increase wellbeing of citizens. A reduction of immigrants and their criminal behaviour plays only a marginal role in increasing feelings of more wellbeing and safety in society (Feltes, 2019, p. 8).

The Bundeskriminalamt (2018a, p. 60) correctly points out that criminal behaviour by immigrants is influenced by the success of their societal integration. 
Unfortunately, refugees tend to face considerable barriers to integration. The reasons are manifold: "those arriving for international protection migrate not because they want to but because they have to; they had little or no time to prepare for migration (for example to collect proof of qualifications or learn the language); their health may have worsened during a long journey; and they often had no contact with the host country before arrival” (OECD, 2018, p. 241). Concerning sexual assaults, the attitude to women in the migrants' home countries play a relevant role (see also Hinton \& Good, 2016).

Given the importance that integration has on crime and given the fact that Germany will continue to require immigration in the future due to its low birth rate, the logical conclusion is that a rational integration policy for immigrants is essential. Although scepticism about immigration has risen, willingness to accept and help refugees remains substantial throughout broad parts of the German population. The Sachverständigenrat Deutscher Stiftungen für Integration und Migration (2018; Roth, 2018) correctly points out that living together with immigrants is judged as a mostly positively experience, especially when cultural diversity is experienced in everyday life.

\section{References}

Aebi, M.F., Berger-Kolopp, L., Burkhardt, C., Chopin, J., Hashimoto, Y.Z., \& Tiago, M.M. (2018). Foreign Offenders in Prison and Probation in Europe: Trends from 2005 to 2015 (Inmates) and Situation in 2015 (Inmates and Probationers). Strasbourg: Council of Europe.

Ammar, M. (2014). Peacemaking Circles \& Young Refugees: Building Resilience in Germany. Universität Tübingen.

Arendt, H. (1943). We Refugees. The Menorah Journal, 31 (1), pp. 69-77.

Australian Centre for Posttraumatic Mental Health (2007). Australian Guidelines for the Treatment of Adults with Acute Stress Disorder and Posttraumatic Stress Disorder. ASD and PTSD Treatment Guidelines. Melbourne. Retrieved from: https://www.psychology.org. au/Assets/Files/ACPMH_FullASDandPTSDGuidelines.pdf.

Balica, E., Marinescu, V., Croitoru, C., Ciobanu, E., \& Stöckl, H. (Eds.) (2018). Migration and Crime: Realities and Media Representations. Palgrave Macmillan.

Balluseck, H., von, \& Ringel, J. (2003). Innerfamiliale Gewalt. In: H. von Balluseck (Hrsg.), Minderjährige Flüchtlinge. Sozialisationsbedingungen, Akkulturationsbedingungen und Unterstützungssysteme (pp. 106-117). Opladen.

Bertelsmann Stiftung (2016). Einwanderungsland Deutschland. Factsheet. Gütersloh.

Bertelsmann Stiftung (2017). Willkommenskultur im „Stresstest“. Einstellungen in der Bevölkerung 2017 und Entwicklungen und Trends sei 2011/12. Ergebnisse einer repräsentativen Bevölkerungsumfrage. Gütersloh.

Bertelsmann Stiftung (2018). Wege aus der Flucht. Warum Menschen fliehen. Gütersloh. 
Bosen, R., \& Wiederwald, R. (2018). Arbeitgeber stützen Merkels „Wir schaffen das“. Deutsche Welle, 14.12.2018. Retrieved from: https://www.msn.com/de-de/nachrichten/politik/arbeitgeber-stützen-merkels-wir-schaffen-das/ar-BBQX1Yv?ocid=spartandhp.

Bräutigam, B. (2000). Der ungelöste Schmerz. Perspektiven und Schwierigkeiten der therapeutischen Arbeit mit Kindern politisch verfolgter Menschen. Gießen.

Brückner, H., Hauptmann, A., \& Vallizadeh, E. (2015). Flüchtlinge und andere Migranten am deutschen Arbeitsmarkt: Der Stand im September. Nürnberg: Institut für Arbeitsmarktund Berufsforschung.

Bundesamt für Migration und Flüchtlinge - BAMF (2016). Migrationsbericht 2015. Zentrale Ergebnisse. Forschungszentrum Migration, Integration und Asyl. Nürnberg (www.bamf. bund.de).

Bundeskriminalamt (2018). Polizeiliche Kriminalstatistik - PKS 2017. Wiesbaden: BKA.

Bundeskriminalamt (2018a). Kriminalität im Kontext von Zuwanderung. Kernaussagen Betrachtungszeitraum: 01.01.-31.03.2018. Wiesbaden: Bundeskriminalamt.

Bundeskriminalamt (2018b). Kriminalität im Kontext von Zuwanderung. Bundeslagebild 2017. Wiesbaden: Bundeskriminalamt.

Bundes Psychotherapeuten Kammer - BPtK (2015). BPtK-Standpunkt: Psychische Erkrankungen bei Flüchtlingen. Berlin: BPtK.

Claussen, J.H. (2018). Das Buch der Flucht. München: CH. Beck.

Council of Europe (2005). Council of Europe Convention on Action Against Trafficking in Human Beings. Warsaw: Council of Europe Treaty Service No. 197. Retrieved from: http://www.coe.int/en/web/conventions/full-list/-/conventions/rms/090000168008371d.

Deutscher Bundestag (2018). Jahresbericht der Bundesregierung zum Stand der Deutschen Einheit 2018. Unterrichtung durch die Bundesregierung. Drucksache 19/4560. Berlin.

Diekmann, M.K. (2016). Menschenrechtliche Grenzen des Rückführungsverfahrens in Europa. Baden-Baden: Nomos Verlags-Gesellschaft. Schriften zum Migrationsrecht, 025.

Dilling, H., Mombour, W., \& Schmidt, M.H. (Hrsg.) (2013). Internationale Klassifikation psychischer Störungen: ICD-10 Kapitel V (F) Klinisch-diagnostische Leitlinien. München: Huber.

Elbert, T., Wilker, S., Schauer, M., \& Neuner, F. (2016). Dissemination psychotherapeutischer Module für traumatisierte Geflüchtete. Erkenntnisse aus der Traumaarbeit in Krisen- und Kriegsregionen. Der Nervenarzt, 88(1), pp. 26-33. DOI: 10.1007/s00115-016-0245-3.

Ellis, B.H., MacDonald, H.Z., Lincoln, A.K., \& Cabral, J. (2008). Mental Health of Somali Adolescent Refugees: The Role of Trauma, Stress, and Perceived Discrimination. Journal of Consulting and Clinical Psychology, 76(2), pp. 184-193. DOI: 10.1037/0022006X.76.2.184.

Enste, D., Eyerund, T., Schneider, R., Schmitz, E., \& Baal, S. van (2016). Die gesellschaftliche Verantwortung von Unternehmen angesichts neuer Herausforderungen und Megatrends. Gütersloh: Bertelsmann Stiftung.

Enzmann, D., \& Kammigan, I. (2018). Parental Violence, Deprivation and Migrant Background. In: S. Roché, \& M. Hough (Eds.), Minority Youth and Social Integration (pp. 81-101). New York: Springer Internat. Publishing,

Erentaité, R., Lannegrand-Willems, L., Negru-Subtirica, O., Vosylis, R., Sondaité, J., \& Raižienë, S. (2018). Identity Development Among Ethnic Minority Youth: Integrating 
Findings from Studies in Europe. European Psychologist, 23(4), pp. 324-335. DOI: 10.1027/1016-9040/a000338.

Eurobarometer, Standard (2014). Nationaler Bericht Deutschland. Die öffentliche Meinung in der Europäischen Union im Herbst 2014. Retrieved from: http://docs.dpaq.de/8574nationaler_bericht.pdf.

European Commission (2004). Report of the Experts Group on Trafficking in Human Beings. Brussels: EU. Retrieved from: https://ec.europa.eu/anti-trafficking/eu-policy/reportexperts-group-trafficking-human-beings_en.

Fazel, M., Wheeler, J., Danesh, J. (2005). Prevalence of Serious Mental Disorder in 7000 Refugees Resettled in Western Countries: A Systematic Review. The Lancet, 365(9467), pp. 1309-1314. DOI: 10.1016/S0140-6736(05)61027-6.

Feltes, T. (2019). Die „German Angst“. Woher kommt sie, wohin führt sie? Innere vs. gefühlte Sicherheit. Der Verlust an Vertrauen in Staat und Demokratie. Neue Kriminalpolitik, 31, pp. 3-12. DOI: 10.5771/0934-9200-2019-1-3.

Feltes, T., List, K., \& Bertamini, M. (2018). More Refugees, More Offenders, More Crime? Critical Comments with Data from Germany. In: H. Kury, \& S. Redo (Eds.), Refugees and Migrants in Law and Policy: Challenges and Opportunities for Global Civic Education (pp. 599-624). Heidelberg, New York: Springer.

Flatten, G., Gast, U., Hofmann, A., Knaevelsrud, C., Lampe, A., Liebermann, P., Maercker, A., Reddemann, L., \& Wöller, W. (2011). S3-Leitlinie Posttraumatische Belastungsstörung ICD 10: F 43.1. Trauma \& Gewalt, 5(3), pp. 202-211.

Foa, R.S., \& Mounk, Y. (2017). The Signs of Deconsolidation. Journal of Democracy, 28(1), pp. 5-16.

Gäbel, U., Ruf, M., Schauer, M., Odenwald, M., \& Neuner, F. (2005). Prävalenz der posttraumatischen Belastungsstörung bei Asylbewerbern in Deutschland und Versuch der Erfassung der Störung im Rahmen der Asylverfahrenspraxis. Zeitschrift für Klinische Psychologie und Psychotherapie, 35(1), pp. 12-20.

Gojer, J., \& Ellis, A. (2014). Post-Traumatic Stress Disorder and the Refugee Determination Process in Canada: Starting the Discourse. New Issues in Refugee Research: Research Paper No. 270. Geneva: UNHCR. Retrieved from: http://www.unhcr.org/533356b349.pdf.

Haverkamp, R. (2016). Geflüchtete Menschen in Deutschland. Zuwanderung, Lebenslagen, Integration, Kriminalität und Prävention - ein Überblick. Bonn: Stiftung Deutsches Forum für Kriminalprävention - DFK.

Haverkamp, R. (2018). Immigration of Refugees into Northwest Europe: Austria, Belgium, France, Germany, the Netherlands, and the United Kingdom. In: H. Kury, \& S. Redo (Eds.), Refugees and Migrants in Law and Policy: Challenges and Opportunities for Global Civic Education (pp. 37-73). Heidelberg, New York: Springer.

Heinz, W. (2012). Personen mit Migrationshintergrund als Opfer und Täter. Migration und Soziale Arbeit, 34, pp. 301-310.

Hestermann, T. (2018). Refugees and Migrants in the Media: The Black Hole. In: H. Kury, \& S. Redo (Eds.), Refugees and Migrants in Law and Policy: Challenges and Opportunities for Global Civic Education (pp. 125-136). Heidelberg, New York: Springer.

Hillebrecht, J., Zeiss, T., \& Bengel, J. (2018). Psychological and Organizational Aspects of Migration of a Special Group of Refugees: The Example of the Special Quota Project Baden-Wuerttemberg with Yazidi Women and Children in Freiburg. In: H. Kury, \& 
S. Redo (Eds.), Refugees and Migrants in Law and Policy: Challenges and Opportunities for Global Civic Education (pp. 355-366). Heidelberg, New York: Springer.

Hinton, D.E., \& Good, B.J. (Eds.) (2016). Culture and PTSD: Trauma in Global and Historical Perspective. Philadelphia: University of Pennsylvania Press.

Ilić, A. (2018). Media Reporting on Refugees and Related Public Opinion in Serbia. In: H. Kury, \& S. Redo (Eds.), Refugees and Migrants in Law and Policy: Challenges and Opportunities for Global Civic Education (pp. 137-161). Heidelberg, New York: Springer.

Infocenter R+V Versicherung (2018). Die Ängste der Deutschen 2018. Wiesbaden: R+V-Versicherung.

Institute for Economics and Peace (2017a). Global Peace Index 2017 - Vision of Humanity: Measuring Peace in a Complex World. Sydney.

Institute for Economics and Peace (2017b). Global Peace Index 2017: Measuring Peace in a Complex World. Sydney.

Jiranek, P., Wehner, T., \& Kals, E. (2015). Soziale Gerechtigkeit - ein eigenständiges Motiv für Freiwilligenarbeit. In: T. Wehner, S.T. Güntert (Hrsg.), Psychologie der Freiwilligenarbeit (pp. 95-108). Berlin, Heidelberg: Springer.

Johansson, S. (2016). Was wir über Flüchtlinge (nicht) wissen. Der wissenschaftliche Erkenntnisstand zur Lebenssituation von Flüchtlingen in Deutschland. Eine Expertise im Auftrag der Robert Bosch und des SVR-Forschungsbereichs. Berlin.

Kessler, R.C. (2007). The Global Burden of Anxiety and Mood Disorders: Putting the European Study of the Epidemiology of Mental Disorders (ESEMeD) Findings into Perspective. Journal of Clinical Psychiatry, 68, pp. 10-19.

Klingst, M., \& Venohr, S. (2017). Wie kriminell sind Flüchtlinge? Was die Kriminalstatistiken der Bundesländer über die Zunahme von Gewalttaten seit 2015 verraten: Sechs Trendmeldungen zur Zuwanderungskriminalität. Die Zeit Online, 19.04.2017.

Knipper, M., \& Bilgin, Y. (2009). Migration und Gesundheit. Berlin.

Kösemen, O. (2018). Bürgersinn in der Einwanderungsgesellschaft. Was Menschen in Deutschland unter einem guten Bürger verstehen. Gütersloh: Bertelsmann Stiftung.

Kury, H., \& Redo, S. (Eds.) (2018). Refugees and Migrants in Law and Policy: Challenges and Opportunities for Global Civic Education. Heidelberg, New York: Springer.

Kury, H., Dussich, J.P.J., \& Wertz, M. (2018). Migration in Germany: An International Comparison on the Psychotraumatic Stress Among Refugees. In: H. Kury, S. Redo (Eds.), Refugees and Migrants in Law and Policy: Challenges and Opportunities for Global Civic Education (pp. 313-354). Heidelberg, New York: Springer.

Lennertz, I. (2011). Trauma und Bindung bei Flüchtlingskindern. Erfahrungsverarbeitung bosnischer Flüchtlingskinder in Deutschland. Göttingen: Vandenhoeck \& Ruprecht.

Lien, H.H. (2016). Migrants on the European Labour Market. Some Results from the European Labour Force Survey ad hoc module 2014. Wiesbaden: Statistisches Bundesamt.

Light, M.T., \& Miller, T. (2018). Does Undocumented Immigration Increase Violent Crime? Criminology, 56(2), pp. 370-401. DOI: 10.1111/1745-9125.12175.

Lindert, J., Brähler, E., Wittig, U., Mielck, A., \& Priebe, S. (2008). Depressivität, Angst und Posttraumatische Belastungsstörung bei Arbeitsmigranten, Asylbewerbern und Flüchtlingen - Systematische Übersichtsarbeit zu Originalstudien. Psychotherapie - Psychosomatik - Medizinische Psychologie, 58(3-4), pp. 109-122. DOI: 10.1055/s-2008-1067358. 
Ludwig, E. (2016). Risk Assessment and the Safe Return and Reintegration of Trafficked Persons. Archiwum Kryminologii, 38, pp. 141-160.

Mediendienst Integration (2018). Zahl der Flüchtlinge. Berlin. Retrieved from: https://mediendienst-integration.de/migration/flucht-asyl/zahl-der-fluechtlinge.html.

Ministerium für Inneres, ländliche Räume und Integration Schleswig-Holsteins (2018). Landesregierung unterstützt DRK-Projekt „Integration durch Integrierte”. Kiel. Retrieved from: https:/www.schleswig-holstein.de/DE/Landesregierung/IV/Presse/ PI/2018/180920_IntegrationDurchIntegrierte.html.

Möllers, M.H.W., \& Ooyen, R.C. van (2018). Flüchtlingskrise. Verlag für Polizeiwissenschaft. Jahrbuch Öffentliche Sicherheit, Sonderband 020.

Moran, M. (2013). Psychiatrists Have a Role in Assessing Candidates for Asylum. Psychiatric News. June 12. Retrieved from: http://psychnews.psychiatryonline.org/newsarticle. aspx?articleid=1698391. DOI: 10.1176/appi.pn.2013.6b15.

OECD (2018). Good Jobs for All in a Changing World of Work: The OECD Jobs Strategy. Paris: OECD Publishing. Retrieved from: https://read.oecd-ilibrary.org/social-issues-migration-health/good-jobs-for-all-in-a-changing-world-of-work_9789264308817-en\#page1.

Ramm, W. (2018). Prozess zu Misshandlungen im Asylbewerberheim. Geldstrafe gegen Geständnis. Spiegel Online, 8.11.2018.

Roth, W. (2018). Volunteers Change the Lives of Refugees and the Entire Society. In: H. Kury, S. Redo, (Eds.), Refugees and Migrants in Law and Policy: Challenges and Opportunities for Global Civic Education (pp. 771-801). Heidelberg, New York: Springer.

Rousseau, C., Pottie, K., Thombs, B.D., Munoz, M., \& Jurcik, T. (2011). Post Traumatic Stress Disorder: Evidence Review for Newly Arriving Immigrants and Refugees. Canadian Medical Association Journal. Montreal: Canadian Collaboration for Immigrant and Refugee Health (CCIRH). Retrieved from: http://www.cmaj.ca/content/suppl/2010/06/07/ cmaj.090313.DC1/imm-ptsd-11-at.pdf.

Ruf, M., Schauer, M., \& Elbert, T. (2010). Prävalenz von traumatischen Stresserfahrungen und seelischen Erkrankungen bei in Deutschland lebenden Kindern von Asylbewerbern. Zeitschrift für Klinische Psychologie und Psychotherapie, 39(3), pp. 151-160. DOI: 10.1026/1616-3443/a000029.

Sachverständigenrat deutscher Stiftungen für Integration und Migration (2018). Stabiles Klima in der Integrationspolitik Deutschland. SVR-Integrationsbarometer 2018. Berlin: SVR.

Schaffer, B., \& Obergfell-Fuchs, J. (2018). Refugees and Migrants in German Prisons: Outlining Problems and Solutions. In: H. Kury, S. Redo (Eds.), Refugees and Migrants in Law and Policy: Challenges and Opportunities for Global Civic Education (pp. 647-667). Heidelberg, New York: Springer.

Schatz, H. (2019). Justizvollzug in der Einwanderungsgesellschaft. Retrieved from: https:// www.hamburg.de/justizbehoerde/justizvollzug/12352948/19-3-21-fachtagung-redeholger-schatz/.

Scheerer, S. (1978). Der politisch-publizistische Verstärkerkreislauf. Kriminologisches Journal, 10(3), pp. 223-227.

Scherr, A. (2018). Who Can Claim Protection as a Refugee? A Sociological Critique of the Distinction Between Refugees and Migrants. In: H. Kury, S. Redo (Eds.), Refugees and Migrants in Law and Policy: Challenges and Opportunities for Global Civic Education (pp. 111-123). Heidelberg, New York: Springer. 
Simon, R.I. (Ed.) (1995). Posttraumatic Stress Disorder in Litigation: Guidelines for Forensic Assessment. Arlington, VA: American Psychiatric Press.

Statista - Das Statistik-Portal (2018). Geschätzte Anzahl der im Mittelmeer ertrunkenen Flüchtlinge in den Jahren von 2014 bis 2018. Hamburg: Statista GmbH. Retrieved from: https:/de.statista.com/statistik/daten/studie/892249/umfrage/im-mittelmeer-ertrunkenen-fluechtlinge/.

Statistisches Bundesamt - Destatis (2018a). Rechtspflege. Strafvollzug - Demographische und kriminologische Merkmale der Strafgefangenen zum Stichtag. 31.3.2018. Berlin.

Statistisches Bundesamt - Destatis (2018b). Geburten. Wiesbaden. Retrieved from: https:// www.destatis.de/DE/ZahlenFakten/GesellschaftStaat/Bevoelkerung/Geburten/Geburten.html.

Strack, R., Baier, J., Keupp, D., Renz, A., \& Rietschel, C. (2015). Die halbierte Generation. Die Entwicklung des Arbeitsmarktes und ihre Folgen für das Wirtschaftswachstum in Deutschland. Boston/USA: The Boston Consulting Group.

Täubig, V. (2009). Totale Institution Asyl. Empirische Befunde zu alltäglichen Lebensführungen in der organisierten Desintegration. Weinheim, München: Juventa-Verl.

Teegen, F. (2003). Posttraumatische Belastungsstörungen bei gefährdeten Berufsgruppen: Prävalenz - Prävention - Behandlung. Bern et al.: Huber.

Thränhardt, D. (2015). Die Arbeitsintegration von Flüchtlingen in Deutschland. Humanität, Effektivität, Selbstbestimmung. Gütersloh: Bertelsmann Stiftung.

Toshkov, D., \& Kortenska, E. (2015). Does Immigration Undermine Public Support for Integration in the European Union? Journal of Common Market Studies, 53(4), pp. 910-925. DOI: $10.1111 /$ jcms.12230.

UNHCR - United Nations High Commissioner for Refugees (2013). The Future of Syria: Refugee Children in Crisis. Retrieved from: www.unhcr.org/FutureOfSyria.

UNHCR - The UN Refugee Agency (2018). Gobal Trends. Forced Displacement in 2017: The United Nations High Commissioner for Refugees. Genf.

Walburg, C. (2018). Angekommen und zugehörig? Migration, Integration und Jugenddelinquenz. Monatsschrift für Kriminologie und Strafrechtsreform, 101(1), pp. 16-45. DOI: 10.1515/mkr-2018-1010103.

Weathers, F., Litz, B., Herman, D., Huska, J., \& Keane, T. (1993). The PTSD Checklist (PCL): Reliability, Validity, and Diagnostic Utility. Paper Presented at the Annual Convention of the International Society for Traumatic Stress Studies, San Antonio, TX.

Wike, R., \& Fetterolf, J. (2018). Liberal Democracy’s Crisis of Confidence. Journal of Democracy, 29(4), pp. 136-150. DOI: 10.1353/jod.2018.0069.

Willems, D., \& van Santen, E. (2018). Opfer gleich Täter? Junge Menschen in Deutschland und Erfahrungen körperlicher Gewalt - Ergebnisse der DJI-Studie „Aufwachsen in Deutschland: Alltagswelten II”. Monatsschrift für Kriminologie und Strafrechtsreform, 101(1), pp. 46-61.

Wilson, J.P., \& Keane, T.M. (Eds.) (1997). Assessing Psychological Trauma and PTSD. New York: The Guilford Press. 